\title{
Security in CAI Materials by Embedding Digital Watermark
}

\author{
S. Nitsuwat and J. Srisomphun \\ King Mongkut's Institute of Technology North Bangkok, Thailand \\ sns@kmitnb.ac.th jsp@kmitnb.ac.th
}

\begin{abstract}
Computer-based instruction assistance (CAI) plays very important role in e-learning system. Distancelearning students can remotely access this kind of course materials. However, being an electronic form has created a growing need to protect them against illegal manipulation and duplication. Therefore, the more robust techniques are needed. Digital watermarking has been proposed as a solution to the problem of copyright protection of multimedia for many decades. This technique can also be applied to the educational frameworks. In this paper, before the CAI will be distributed, double watermarks have been embedded into all still images in the CAI materials. Firstly, the visible watermark, e.g., university's logo, is inserted directly on image pixel's intensity to exhibit an ownership of the CAI. The fragile invisible watermark is then embedded again on these watermarked images. Because of the special characteristic of the latter if there is any attempt to change or remove the visible logo, it can be clearly detected. We also proposed the extracting method to reveal secret information using for verifying our right on the materials. The experiments using different kinds of attacks on the materials are also conducted. Finally, the discussion of the experimental results and conclusion of the paper are also given.
\end{abstract}

Keywords: Information technology for education, CAI Security, Ownership Authentication, Visible Watermark, Fragile Watermark

[Research-in-Progress Paper]

\footnotetext{
Material published as part of these proceedings, either on-line or in print, is copyrighted by Informing Science. Permission to make digital or paper copy of part or all of these works for personal or classroom use is granted without fee provided that the copies are not made or distributed for profit or commercial advantage AND that copies 1) bear this notice in full and 2) give the full citation on the first page. It is permissible to abstract these works so long as credit is given. To copy in all other cases or to republish or to post on a server or to redistribute to lists requires specific permission from the publisher at Publisher@InformingScience.org
} 